\title{
ALLAH SEGALA MAHA DI TENGAH FENOMENA KEKERASAN DAN PENDERITAAN ORANG SALEH
}

\author{
Jusuf Haries Kelelufna
}

\begin{abstract}
The violence and suffering of the righteous are a unique issue in Christianity because they relate to the "all-great" nature of God. The existence of God "all great" with the existence of evil can not be ignored but also can not be "reconciled". The attempts to reconcile them generate the possibility of an answer to the suffering of the pious man that God is not "all-great" or even God is not. The author analyzes the logic of thinking by considering: terms, places, processes of argumentation and conclusions to answer the problem. The author records the solution to the problem of the suffering of the righteous with an emphasis on the loving, just, omnipotent nature of God. But God's love, justice, and power are not the same as understanding the love, justice and human power. One possible answer to the question can not be generalized to all cases of suffering. Suffering itself can have a positive (transformative) but also negative (destructive) impact on the patient depending on the maturity level of the patient in dealing with it
\end{abstract}

Keywords: Violence, Suffering, Righteousness, God Nature

\begin{abstract}
Abstrak
Kekerasan dan penderitaan yang dialami orang saleh merupakan persoalan yang unik dalam kekristenan sebab berhubungan dengan sifat Allah yang"segala maha".Adanya eksistensi Allah "segala maha" dengan eksistensi kejahatan tidak dapat diabaikan namun juga tidak dapat "didamaikan". Berbagai usaha untuk mendamaikannya memunculkan kemungkinan jawaban terhadap penderitaan orang saleh bahwa Allah tidak "segala maha" atau bahkan Allah tidak ada. Penulis menganalisis jalannya logika berpikir dengan mempertimbangkan: syarat, tempat, proses argumentasi serta kesimpulan untuk menjawab persoalan tersebut. Penulis mencatat solusi terhadap persoalan penderitaan orang saleh dengan penekanan pada sifat Allah yang mengasihi, adil, maha kuasa. Namun kasih, keadilan, dan kuasa Allah tidak sama dengan pengertian kasih, keadilan dan kuasa manusia. Satu kemungkinan jawaban terhadap persoalan tersebut tidak dapat digeneralisir untuk semua kasus penderitaan. Penderitaan itu sendiri dapat berdampak positif (transformatif) tetapi juga negatif (destruktif) bagi penderita tergantung tingkat kedewasaan penderita dalam menghadapinya.
\end{abstract}

Kata Kunci: Kekerasan, Penderitaan, Orang Saleh, Sifat Allah 


\section{PENDAHULUAN}

Kekerasan dan penderitaan dialami oleh manusia tanpa memandang agama, suku dan golongan serta terjadi di berbagai tempat. Pengalaman kekerasan dan penderitaan yang universal ini menjadi masalah utama teologis bagi Yudaisme maupun kekristenan yang memercayai adanya kebaikan Allah. Bahkan, menjadi persoalan sebagian besar agama karena pada hakikatnya agama-agama tersebut mengajarkan tentang Allah yang maha baik. Dalam bentuk-bentuk praktisnya, setiap orang memiliki masalah dengan kekerasan dan penderitaan. Semua manusia mengalami realitas hidup dalam dunia dengan perasaan terluka, kekejaman, menderita sakit, kekerasan, kecelakaan, kehilangan, penyiksaan, penderitaan emosional dan fisik, serta kematian. Namun, bentuk-bentuk teoritik tentang kekerasan dan penderitaan merupakan persoalan yang unik dalam kekristenan sebab berhubungan dengan sifat Allah "segala maha". Istilah "segala maha" penulis gunakan dalam pengertian yang positif seperti: maha kasih, maha mengetahui, maha adil, maha hadir, maha kuasa dan lain-lain. Di mana kekerasan dan penderitaan orang saleh terlihat kontras dengan sifat-sifat Allah yang serba maha tersebut. Di satu sisi Allah yang maha kuasa sehingga Dia dapat mencegah semua kekerasan dan penderitaan namun kenyataannya Dia tidak melakukannya. Di sisi lain, Allah adalah kasih yang tentu saja dalam kasih-Nya, Dia tidak mengijinkan kejahatan dan penderitaan namun kenyataannya Dia tidak melakukannya. Allah yang maha adil memungkinkan untuk membenarkan teologi pembalasan bahwa Allah akan berlaku adil bagi setiap orang sesuai dengan perbuatannya. Namun, Alkitab juga mencatat bahwa penderitaan tidak hanya dialami oleh orang fasik, melainkan juga oleh orang-orang saleh dan fakta empiris menegaskan hal tersebut. Keadaan ini pada akhirnya mempertanyakan kesalehan umat Tuhan yang menderita atau sebaliknya mempertanyakan sifat-sifat Allah. Dengan demikian, persoalannya adalah bahwa dengan adanya kekerasan dan penderitaan berisi ketidakmungkinan Allah maha tahu, maha kuasa, Allah menyayangi-semua sebab memberikan kesan suatu ketidakkonsistenan logika berpikir. Dengan demikian, bagaimana mungkin memercayai eksistensi Allah yang mahakuasa dan Allah yang mengasihi ditengah-tengah dunia yang penuh dengan kekerasan dan penderitaan. Di sisi yang lain dengan meyakini bahwa Allah itu adil, maka logikanya adalah bahwa adil berarti Ia akan memberikan imbalan kepada 
kebaikan dan menghukum kejahatan, dan imbalan yang diberikan-Nya akan membuat penerimanya bahagia sebaliknya penderita tidak bahagia. Sehingga dapat disimpulkan bahwa penderita adalah orang jahat dan orang yang bahagia adalah orang baik. Persoalan teologis ini telah lama diperdebatkan namun menurut penulis adanya fenomena kekerasan dan penderitaan orang saleh saat ini menjadikan topik ini tetap relevan untuk dibahas. Persoalan ini merupakan tantangan teologis karena tidak dapat menyangkali adanya realitas kekerasan dan penderitaan, namun di sisi lain ketika mencoba untuk mendamaikan realitas tersebut dengan kuasa dan kebaikan Allah maka akan memimpin kepada apa yang oleh Stoeber disebut sebagai, "serangan terhadap pertumbuhan teologi."1

Penulis menganalisis jalannya logika berpikir sebagaimana yang diusulkan oleh Kreeft, untuk menjawab persoalan kekerasan dan penderitaan yang dialami oleh orang saleh dalam hubungannya dengan Tuhan, yang memiliki sifat segala maha serta mengemukakan berbagai kemungkinan sikap terhadap Allah sebagai jawaban atas persoalan penderitaan orang saleh. Menurut Kreeft, untuk menganalisa jalannya logika perlu mempertimbangkan: syarat, tempat, proses argumentasi serta kesimpulan. Menurutnya, jika syarat tidak ambigu, tempat tidak palsu, dan proses argumentasi tidak logis atau keliru, maka kesimpulannya terbukti benar dan tidak ada alasan untuk menentangnya. ${ }^{1}$ Kajian terhadap persoalan teologis ini dibatasi pada bagaimana "mendamaikan" fenomena penderitaan yang dialami orang saleh dengan sifat Allah "segala Maha".

\section{ISTILAH KEKERASAN DAN PENDERITAAN DALAM ALKITAB}

Istilah kekerasan dalam Perjanjian Lama (selanjutnya disingkat PL) berasal dari istilah Ibrani khāmās yang oleh KJV, RSV dan NIV diterjemahkan dengan violence. Istilah ini dalam Alkitab PL meliputi kekerasan fisik dan psikis. Kata ini digunakan hampir selalu berhubungan dengan dosa kekerasan. Namun, kekerasan di sini tidak berhubungan bencana alam, atau kasus kekerasan seperti yang ditangani kepolisian sebagaimana ditampilkan pada televisi modern saat ini, melainkan merupakan sebutan bagi dosa yang ekstrem. Misalnya, dosa yang menyebabkan air bah (Kej. 6:11, 13), memberikan kesaksian yang tidak benar (Kel. 23:1; Ul. 19:16), kekejaman kebencian (Maz. 25:19), penindasan dan 
kekerasan (Maz. 72:14), kekerasan sebagai ukuran kejahatan (Yeh. 7:11) dan dalam Kejadian 16:5 istilah khāmās diterjemahkan dengan "penghinaan". Kekerasan mengakibatkan derita terhadap obyeknya, baik secara mental maupun fisik dan berhubungan dengan banyak aspek dalam kehidupan manusia. Istilah derita (deritaan) adalah sesuatu yang diderita seperti kesengsaraan, kesusahan. Sedangkan kata benda penderitaan adalah perihal menderita atau penanggungan. ${ }^{3}$ Selanjutnya, penulis menggunakan istilah penderitaan dalam tulisan ini untuk mengacu pada apa yang dialami oleh orang-orang saleh.

Penulis mengutip dua kata bahasa Ibrani dalam PL untuk menjelaskan konsep penderitaan yaitu kata $k \bar{a}$ 'ab dan $t s \bar{a}$ ' $a q$. Kedua istilah ini mengemukakan penderitaan baik secara fisik dan psikis. Kata $k \bar{a}$ 'ab dalam Kejadian 34:25 diterjemahkan dengan "menderita" namun secara harfiah akar kata ini dapat berarti: sakit, luka, sedih, dukacita dan penderitaan. Kata ini dapat digunakan untuk mengekspresikan penderitaan fisik dan psikis. Di sisi lain, sulit untuk memisahkan antara penderitaan fisik dan psikis sebagaimana yang dijelaskan oleh kata ini. ${ }^{4}$ Sedangkan istilah berikutnya adalah $t s \bar{a}$ 'aq yang dapat berarti: menangis, berteriak minta tolong dan memanggil. Arti dasar kata $t s \bar{a}$ 'aq adalah teriak minta tolong karena berada di bawah tekanan yang besar. ${ }^{5}$ Dalam beberapa teks kata $t s \bar{a}$ 'aq diterjemahkan dengan "seruan" (Kel. 22:23; 1 Raj. 20:39; Rat. 2:18).

Ada banyak contoh kasus kekerasan dan penderitaan dalam Alkitab namun penulis mengutip teks Kejadian 2-3 dan Mazmur 137 sebagai contoh pengalaman derita yang dialami oleh bangsa Israel. Gerda de Villiers menafsirkan cerita taman Eden dengan cara yang berbeda yaitu dengan melihatnya sebagai Israel yang berjuang karena kehilangan tanah, hilangnya sorga. Hal ini menggambarkan hubungan langsung dengan alasan pembuangan dan sebagai akibatnya adalah penderitaan. Di sisi lain, Kejadian 2-3 juga menjadi pedoman filsafat tentang bagaimana hidup dalam pembuangan. Pembuangan tidak harus secara fisik, pengasingan geografis tetapi juga dapat berupa pengalaman psikologis di antara teman-teman, keluarga dan kolega, dan ini adalah penderitaan yang paling buruk. ${ }^{6}$ Terlepas dari pendekatan de Villiers, teks Kejadian 2-3 secara spesifik menyebutkan tentang kesakitan waktu melahirkan dan susah payah dalam mencari rezeki (Kej 3:16, 17). 
Becking, menguji Mazmur 137 yang menggambarkan penderitaan walaupun dalam cara yang terbatas yakni menggambarkan nasib Yehuda di pembuangan. Namun, gambaran yang timbul dari arkeologi dan epigrafi menunjukkan bahwa kelompok ini hidup dalam kondisi yang relatif baik. Membaca Mazmur 137 dalam latar belakang ini menghasilkan tema tentang pengasingan dan ambivalensi.Penderitaan real tidak ditemukan dalam kehidupan mereka setiap hari tetapi faktanya bahwa mereka diasingkan dari Zion. ${ }^{7}$ Artinya bahwa penderitaan tidak hanya terjadi pada seseorang yang kondisinya terlihat buruk, tetapi juga dapat dialami oleh seseorang yang hidup dalam kondisi yang relatif baik.

Penggunaan kata-kata bahasa Ibrani khāmās, $k \bar{a}$ 'ab dan $t s \bar{a}$ 'aq serta analisis terhadap Kejadian 2-3 dan Mazmur 137, memberi pesan bahwa penderitaan tidak hanya dialami oleh seseorang yang berada dalam kondisi yang buruk melainkan juga dapat dialami oleh seseorang yang hidup dalam kondisi yang relatif baik. Itulah sebabnya penampilan lahiriah seseorang tidak dapat digunakan sebagai indikator untuk menilai apakah dia menderita ataukah tidak. Hal ini disebabkan karena penderitaan tidak hanya secara fisik tetapi juga secara psikis. Browning membagi penderitaan dalam Alkitab secara umum menjadi dua macam yaitu: pertama, penderitaan yang dialami karena kemanusiaan yang meliputi derita sakit, kehilangan, kekhawatiran dan depresi. Dan kedua, penderitaan yang didatangkan atas umat Allah yang disebabkan oleh penganiayaan atau pengekangan diri pribadi. ${ }^{8}$ Selanjutnya analisis terhadap topik ini dibatasi pada penderitaan orang saleh karena kesalehannya atau penderitaan "yang tidak layak" diterima oleh seseorang namun penderitaan itu didatangkan atasnya.

\section{PENDERITAAN ORANG SALEH}

Alkitab menyaksikan penderitaan orang-orang saleh, baik dalam PL maupun PB. Dalam PL, bangsa Israel yang adalah umat pilihan Allah secara kolektif bergumul dengan persoalan penderitaan dimulai dari perbudakan di Mesir, perjalanan ke tanah Kanaan hingga pembuangan ke Babel. Selain itu, sejarah mencatat bahwa mereka pernah tersebar di Eropa hingga akhirnya mereka kembali ke tanah Israel sekarang ini. Secara pribadi tokoh-tokoh tertentu dalam PL juga bergumul dengan penderitaan misalnya; Gideon (Hak. 6), Hana (1 Sam. 1), Elimelek (Rut 1), Ayub dan yang lainnya. Demikian juga dengan PB yang 
dimulai dengan penderitaan Tuhan Yesus dalam karya penebusannya sehingga terkesan bahwa, gambaran Yesus menurut Perjanjian Baru rupanya memberi kesan, bahwa kekejaman atau kekerasan dilihatnya sebagai penebusan Allah. ${ }^{9}$

Persoalan penderitaan yang dialami oleh orang saleh juga menjadi pengalaman orang saleh dewasa ini di berbagai belahan dunia. Dalam konteks Amerika, James H. Cone menyajikan penderitaan orang-orang kulit hitam dan beberapa orang kulit putih. Menurutnya, kita mungkin dengan aman dapat menganggap bahwa orang Amerika berkulit hitam menderita secara psikis dari waktu dahulu hingga kini. ${ }^{10}$ Memang ini adalah isu rasial di Amerika namun penulis menyebutkannya karena di antara mereka ada yang hidup benar di hadapan Tuhan. Dalam konteks Kekristenan di Indonesia, umat beragama termasuk agama Kristen selalu diperhadapkan dengan diskriminasi atas dasar isu mayoritas dan minoritas baik antar agama maupun inter agama. Persoalan yang tak kunjung selesai tentang larangan beribadah dan pembongkaran gereja menjadi bagian dari derita yang dijalani oleh orang-orang percaya di Indonesia. Selain itu persoalan ekonomi, politik, sosial dan budaya juga berdampak baik secara langsung maupun tidak langsung terhadap "derita" masyarakat bangsa Indonesia. Tidak terkecuali orang-orang yang hidup benar di hadapan Tuhan. Misalnya, ketika terjadi kesenjangan sosial, krisis keuangan, krisis keamanan dan sebagainya maka akan menimpa semua anak bangsa tidak hanya dari golongan dan atau agama tertentu saja.

Kenyataan ini menunjukkan persoalan teologis yang berhubungan dengan sifat Allah. Ketika penderitaan dilihat sebagai akibat langsung dari perbuatan dosa seseorang maka mungkin saja dapat diterima secara umum, namun ketika hal itu menimpa orang benar yang melayani Tuhan yang adil, Tuhan yang mengasihi, Tuhan yang maha kuasa, Tuhan yang maha tahu maka akan sulit untuk diterima dengan nalar manusia. Pembahasan ini mendasari penjelasan selanjutnya tentang kekerasan dan penderitaan dalam hubungannya dengan Allah yang memiliki sifat "segala maha" tersebut. Di satu sisi kesalehan penderita sering dipertanyakan, di sisi lain beberapa orang ketika berada dalam penderitaan yang "tidak layak diterimanya" akan sampai pada kesimpulan bahwa Allah "tidak mahakuasa", "tidak adil" dan atau "tidak mengasihi" karena seakan-akan Allah setuju dengan kekerasan dan penderitaan. 
Dalam beberapa kasus, Allah seakan berdiam ketika umat-Nya berada dalam penderitaan. Wayne Morris menggunakan istilah "teologi bisu" yang dikenakannya kepada "Yesus yang bisu" dan juga kepada "komunitas yang bisu". Menurutnya, diskusi tentang diamnya Allah mendemonstrasikan pergerakan yang signifikan jauh dari argumentasi beberapa teolog disability sebab "teologi bisu" adalah keprihatinan bukan dengan pengalaman pribadi Yesus yang disabilitas melainkan dengan Yesus sejarah dan kemampuan iman Kristus untuk berhubungan dan terbawa dengan komunitas bisu. ${ }^{11}$ Komunitas bisu juga bukan dalam pengertian disabilitas melainkan dalam pengertian tidak dapat menyuarakan penderitaan mereka sendiri tetapi juga dalam pengertian teriakan mereka yang tidak terdengar. Kadang penderitaan terjadi ketika perasaan pribadi seseorang tidak bersuara. Dalam hal ini, dapat terjadi ketika sesorang berdiam diri dan tidak menceritakan pengalamannya atau ketika ia“menjerit" namun jeritannya tidak terdengar.

\section{PENDERITAAN ORANG SALEH DAN ALLAH SEGALA MAHA}

Pengalaman derita yang dialami oleh orang fasik akan dengan mudah diterima oleh banyak orang. Hal ini didasarkan pada pemahaman teologis tentang penderitaan retributive, yaitu pandangan Alkitab ortodoks yang melihat penderitaan sebagai balasan atas dosa. Pandangan ini tidak hanya terdapat di kalangan Agama Kristen, melainkan juga dalam agama lainnya dengan menggunakan terminologi yang berbeda-beda. Misalnya, Yifa ketika menjelaskan tentang karma dalam agama Budha mengungkapkannya dalam bahasa sebab dan akibat. ${ }^{12}$ Namun, ketika pengalaman penderitaan dihubungkan dengan orangorang saleh, maka hal ini menjadi persoalan teologis yang telah diperdebatkan lama sebelumnya. Penderitaan orang yang tidak bersalah merupakan tantangan teologi yang sangat signifikan pada tradisi monoteistik umumnya dan khususnya Yudaisme. ${ }^{13}$ Dalam bagian ini, penulis melihat berbagai kemungkinan hubungan antara realitas kekerasan dan penderitaan dengan kuasa dan kebaikan Allah bukan dalam pengertian untuk "mendamaikannya" melainkan dalam pengertian sebagai misteri Allah.

Kekristenan memercayai adanya satu Allah yang menciptakan semuanya. Allah adalah pribadi yang baik, mengasihi, maha kuasa dan berkuasa atas segala 
yang terjadi. Dengan meyakini kebenaran Alkitabiah yang besar tentang Allah yang hidup, tidak menjadi persoalan tetapi dengan adanya eksistensi kejahatan di sisi lain menimbulkan persoalan. Penerapan yang sama pada argumentasi yang berlawanan dengan eksistensi Allah yaitu dengan eksistensi kejahatan. Di mana, eksistensi kejahatan di dunia adalah jelas pada setiap orang dan secara umum manifestasinya menonjol di dunia pada banyak tempat dan waktu.

\section{a. Theodise dan Penderitaan}

Teologi Kristen menempatkan theodisi di depan dengan pesan untuk menerangkan mengapa sifat maha tahu, maha kuasa, Allah penyayang-semua, namun mengizinkan adanya kejahatan dan penderitaan. Dengan demikian, pemahaman theodisi meruntuhkan kategori kehendak bebas dan kebaikan yang besar. ${ }^{14}$ Theodisi dalam pengertian klasik dapat didefinisikan sebagai upaya untuk mempertahankan keadilan dan kuasa Allah dalam suatu dunia yang dirusak oleh penderitaan. $^{15}$

\section{b. Penderitaan dan Providensia Allah}

Konsep teologi tentang providensia yang universal berimplikasi pada predestinasi, dengan kata lain kepercayaan bahwa setiap peristiwa dan tindakan ada dalam kontrol langsung Allah. Di mana teologi providensia adalah teologi tentang pemeliharaasn Tuhan, sedangkan predestinasi adalah takdir atau nasib. Jadi, jika seseorang menjalani kehidupan yang tidak etis akan berakibat masuk neraka, itulah sebabnya ide penghakiman Allah menjadi tantangan bagi Allah dalam mengontrol tindakan setiap orang. Persoalan besar tentang konsep providensia Allah yaitu dengan memunculkan masalah kejahatan dan penderitaan. Fakta bahwa dunia penuh dengan kekerasan dan penderitaan yang dialami setiap orang menimbulkan sikap skeptis akan adanya kemajuan moral manusia. Manusia memiliki kehendak bebas untuk memilih melakukan sesuatu yang baik ataupun buruk dan bebas untuk memilih dalam membentuk karakter mereka. Dengan demikian, logika seharusnya adalah bahwa kejahatan moral tidak dapat dicegah oleh Allah. Jika Allah mengintervensi untuk menghentikan pilihan buruk manusia maka akan berdampak buruk pada niat manusia, di mana mereka tidak dapat bertanggung jawab secara baik atas dunia. Hal ini berarti setiap pilihan manusia 
disertai dengan konsekuensi yang akan dijalaninya baik ataupun buruk. Lerner mengemukakan adanya dua suara yang menggema dalam Torah yaitu: suara Allah yang digambarkannya sebagai suara belas kasihan dan transendensi. Namun, Torah juga diisi dengan suara lainnya yang mencerminkan distorsi kemanusiaan dan akumulasi kesakitan. Lebih lanjut ia menegaskan bahwa, suara kekejaman bukanlah suara Allah. ${ }^{16}$ Dalam hal ini, kemahakuasaan Allah digunakan selaras dengan kehendak bebas manusia.

\section{c. Allah "Menggunakan" dan atau "Menyebabkan" Penderitaan}

Dalam penjelasan sebelumnya telah ditegaskan, bahwa banyak penderitaan tidak disebabkan oleh dosa, demikian juga bahwa banyak penderitaan tidak disebabkan oleh Allah. Dalam hal ini, perlu diperhatikan perbedaan mendasar antara Allah menguji seseorang lewat penderitaan, ataukah Allah mengizinkan penderitaan sebagai ujian. Jika Allah menguji seseorang lewat penderitaan, itu berarti Allah yang menyebabkan penderitaan. Namun, jika Allah mengizinkan penderitaan sebagai ujian, maka sumber penderitaan itu bukan berasal dari Allah. Dalam hal ini, menurut Croy, Sekarang ini banyak orang memercayai perbedaan antara Allah "menggunakan" dan Allah "menyebabkan" penderitaan, namun perbedaan ini jarang diekspresikan dalam tulisan-tulisan kuno. ${ }^{17}$

Dengan menggunakan istilah Allah "menggunakan" ataukah Allah "menyebabkan" penderitaan akan berdampak pada pengertian penderitaan sebagai kehendak Allah. Apakah Allah "menyebabkan" penderitaan ataukah Allah "menguji" berarti bahwa Allah menghendaki penderitaan? Sebaliknya apakah Allah "menggunakan" atau Allah "mengijinkan" penderitaan artinya Allah tidak menghendaki? Harus diakui bahwa tidak semua penderitaan adalah keinginan Allah, namun ketika subyeknya adalah Allah, maka apakah Ia "menyebabkan" atau "menggunakan" penderitaan tentu saja hal itu merupakan kehendak-Nya. Allah menghendaki kebaikan bagi umat-Nya lewat ketaatan mereka, namun umatNya diberi kebebasan untuk memilih apa yang akan dilakukannya dan ketika mereka memilih untuk tidak taat itupun ada dalam kehendak-Nya sebagai pribadi "segala maha". Menurut penulis, bagian ini penting untuk dibahas sebagai apologet terhadap kesan pemahaman teologi kemakmuran yang muncul dalam pelayanan gereja dewasa ini bahwa Allah menghendaki umatnya diberkati dan 
sebaliknya Allah tidak menghendaki umat-Nya untuk menderita. Pada taraf tertentu memang demikian, namun menjadi persoalan ketika istilah berkat dan derita diinterpretasikannya secara berbeda dan melihat orang yang dalam kondisi kekurangan dan atau sakit-sakitan sebagai orang yang tidak diberkati.

\section{d. Penderitaan adalah Misteri Allah}

Pembahasan sub judul ini berhubungan dengan kekerasan dan penderitaan dalam hubungannya dengan Allah segala maha. Bahwa Allah tidak dapat dimengerti sepenuhnya oleh manusia dan bahwa tidak terselami pekerjaanpekerjaan Allah. Itulah sebabnya perlu mengakui bahwa penderitaan orang saleh adalah misteri Allah. Mengutip pendapat Wright bahwa: Alkitab meminta kita untuk menyetujui bahwa kejahatan adalah misteri, kita tidak dapat menjelaskan pengertiannya secara rasional. Namun Alkitab juga mengizinkan kita untuk membawa ratapan kita dan protes kita ke hadirat Allah dan ikut serta dengan paduan suara dalam Alkitab yang berteriak kepada Allah dengan menanyakan "mengapa"? dan "berapa lama"? mengalami penderitaan iman. ${ }^{18}$

\section{KEMUNGKINAN JAWABAN ATAS PENDERITAAN ORANG SALEH}

Dalam bagian ini, penulis menganalisis kemungkinan jawaban atas penderitaan orang saleh dengan didasarkan pada penderitaan Ayub ketika ia berdialog dengan teman-temannya. Tema dialog mereka juga menjadi tema dialog manusia dewasa ini. Dari dialog mereka, muncullah kemungkinan jawaban atas persoalan mengapa ada kejahatan di alam semesta, yang diciptakan dan diperintah oleh Allah yang baik dan maha kuasa, serta bagaimana bisa Allah yang baik dan kuat membiarkan hal-hal buruk terjadi pada orang baik? Kitab Ayub menjadi dasar dalam penjelasan tema ini karena mengutip pendapatnya Kreeft bahwa, kitab Ayub adalah sebuah teka-teki yang menjawab teka-teki lain. Teka-teki itu menjawab masalah terdalam hidup, masalah kejahatan, penderitaan, ketidakadilan dalam dunia yang seharusnya diperintah oleh Allah yang adil. ${ }^{19}$

Kraemer, mengategorikan penderitaan atas delapan kategori yaitu; pertama, penderitaan retributif; kedua, penderitaan disipliner; ketiga, penderitaan pewahyuan; keempat penderitaan cobaan; kelima penderitan sebagai ilusi (Habakuk dan beberapa Mazmur); keenam penderitaan misterius (hanya Allah 
yang mengerti); ketujuh penderitaan eskatologi (Daniel); dan kedelapan penderitaan yang sia-sia (Pengkhotbah). ${ }^{20}$ Berdasarkan kategori di atas, penulis menjelaskan kemungkinan jawaban atas penderitaan orang benar yang meliputi beberapa kategori di atas. Pembahasan tentang kategori derita tidak secara komperhensif mengikuti pembagian oleh Kraemer, namun hanya beberapa bagian yang menurut penulis sangat berhubungan dengan pemahaman dan perkembangan pelayanan dewasa ini. Berbagai kemungkinan jawaban atas penderitaan orang benar tersebut antara lain:

\section{a. Penderitaan Bukan untuk Orang Baik}

Kemungkinan pertama jawaban atas penderitaan orang benar yaitu penderitaan bukan untuk orang baik, melainkan untuk orang jahat, itulah sebabnya karena Ayub menderita maka kesimpulannya bahwa Ayub bukan orang baik. Dalam konteks kitab Ayub, jawaban ini berasal dari ketiga sahabat Ayub dan itu sangat masuk akal. Jawaban ketiga teman Ayub mewakili pandangan tradisional yakni merupakan jenis penderitaan yang oleh Kraemer disebut dengan penderitaan retributif. Pemahaman teologi seperti ini mengakar dalam kekristenan hingga kini dengan menghubungkan semua penderitaan sebagai akibat dosa.

Implikasi dari pemahaman seperti ini terlihat dalam pelayanan gerejawi yang oleh para "pelayan Tuhan" ketika berhadapan dengan persoalan derita umat maka yang dilakukan adalah mencari dosa apa yang menyebabkan derita tersebut. Pendekatan seperti ini menempatkan penderita dalam kondisi berdosa, dan menuntut pengakuan atas dosanya. Dengan demikian, tanpa sadar sebagai seorang "pelayan Tuhan" telah menghakimi sebelum melayani para penderita tersebut dan di sisi lain menempatkan dirinya sendiri yang tidak sedang berada dalam penderitaan sebagai orang yang tidak berdosa.

Ketika memahami, penderitaan bukan untuk orang baik, melainkan untuk orang berdosa, maka logika berpikir menuntun pada kesimpulan bahwa tidak akan ada orang baik yang menderita, sebaliknya tidak ada orang fasik yang hidup dalam kesenangan. Fakta menunjukkan sebaliknya dan Alkitab sendiri mengakuinya bahwa orang fasik tetap hidup, menjadi tua, bahkan menjadi bertambah-tambah kuat (Ayub 21:7). Nabi-nabi jaman dahulu telah bergumul dalam pelayanannya tentang orang fasik yang mengepung orang benar; itulah 
sebabnya keadilan muncul terbalik (Hab. 1:4). Mereka yang melihat derita semata-mata karena dosa mengabaikan fakta-fakta ini dan kesaksian Alkitab. Pengalaman derita untuk beberapa kasus dalam Alkitab dihubungkan dengan dosa, namun bukan berarti bahwa dapat digeneralisir untuk semua persoalan penderitaan, dengan kata lain tidak semua penderitaan disebabkan oleh dosa.

Kecenderungan pendapat bahwa penderitaan bukan untuk orang baik muncul dari para "pengamat" penderitaan. Penulis menggunakan istilah "pengamat" dalam pengertian mereka yang tidak sedang menderita namun memberikan penilaian kepada penderita dan hasilnya akan sangat subyektif. Para "pengamat" tersebut apakah mereka yang hanya memberikan penilaian atau mereka yang terlibat dalam pelayanan kepada para penderita. Pendapat ketiga teman Ayub juga merupakan pendapat "teman-teman" pelayan saat ini yang tidak dapat diterima karena; pertama, jelas itu bukan jawaban dari penulis kitab Ayub, kedua, Allah sendiri membantah jawaban ini baik di awal kitab Ayub ketika ia berbicara kepada Iblis tentang kebajikan Ayub maupun pada akhir kitab ketika ia memuji Ayub dan mencela ketiga sahabat Ayub, dan ketiga, jawaban ini mengurangi misteri kehidupan ke pusat masalah. Itulah sebabnya teman-teman Ayub salah, sebab mereka berpegang pada teori dan bukan pada realitas. Mereka mengatakan bahwa biasanya tidak ada penderitaan orang yang tidak bersalah. Mereka merasa bahwa Ayub tidak mungkin tidak bersalah, berhubungan dengan teori mereka bahwa penderitaan adalah konsekuensi dari kesalahan dan hukuman. $^{21}$

\section{b. Penderitaan sebagai Hukuman}

Pada dasarnya kemungkinan jawaban seperti ini masih merupakan jenis penderitaan retributif. Jika perikop sebelumnya menyoroti tentang penderita yang dipandang sebagai orang yang tidak baik atau pendosa, maka dalam bagian ini menyoroti tentang derita yang dilihatnya sebagai hukuman dan penderita dilihat sebagai "tersangka". Kesimpulan seperti ini didasarkan pada sifat Allah yang membalaskan kepada setiap orang menurut perbuatannya. Dalam hal ini, penderitaan dilihat sebagai akibat dosa tertentu. Isu tentang penderitaan sebagai penghukuman muncul dalam konteks Alkitabiah yang diindikasikan oleh isu hukum, penghakiman, darah, pembalasan, penebusan, pemulihan (restitusi), 
kompensasi, sanksi, koreksi, kutukan dan retribusi. Setiap istilah tersebut memiliki arti tersendiri dalam konteksnya namun merupakan elemen arti secara umum bagi semua isu.

\section{c. Allah tidak Baik}

Kemungkinan jawaban ke tiga yang dikemukakan atas penderitaan orang saleh adalah bahwa Tuhan tidak baik atau Tuhan tidak mengasihi. Dalam hal ini kebaikan atau kasih dipisahkan dari kekuasaan, yaitu bahwa Tuhan berkuasa tetapi Dia tidak baik atau tidak mengasihi. Sangat mungkin argumentasi seperti ini disampaikan oleh penderita yang menilai dirinya sendiri dan membandingkannya dengan orang lain sehingga ia sampai pada kesimpulan bahwa Tuhan tidak baik atau bahwa Tuhan telah memperlakukannya dengan tidak adil. Dengan memisahkan antara keadilan dan kemahakuasaan Tuhan, maka Tuhan yang berkuasa namun tidak baik, tidak dapat dipercayai karena mereka yang mempertanyakan keadilan Tuhan ataupun kebaikan Tuhan biasanya merasa lebih benar atau lebih layak untuk mendapatkan sesuatu yang lebih baik dari pada penderitaan mereka. Dengan demikian, kebaikan diri sendiri lebih baik dari kebaikan Allah dan keadilan diri sendiri lebih adil dari keadilan Allah. Argumentasi yang mempertanyakan kebaikan dan keadilan Allah, perlu disangsikan kebenarannya namun dalam prakteknya tidak sedikit yang sampai pada kesimpulan bahwa Tuhan telah berlaku tidak adil baginya.

\section{d. Allah "Tidak Mahakuasa"}

Kemungkinan jawaban ketiga terhadap persoalan penderitaan adalah penolakan terhadap kemahakuasaan Tuhan. Pendapat ini menganggap bahwa Allah tidak mengontrol secara total karena Allah tunduk pada hukum-hukum alam. Hal ini berarti bahwa orang yang dicintai dan mencintai Allah bukanlah akhir, namun hukum alam adalah yang utama dan berada di atas Allah sendiri. Konsekuensinya adalah mereka yang percaya bahwa Allah yang disembah adalah baik tetapi tidak berkuasa berarti mereka masih menempatkan kebaikan dan etika di tingkat tertinggi sebagai mutlak, tetapi tidak bisa memercayai atau mengharapkan yang baik untuk menang. Konsep ini sama dengan pemikiran teologi proses yang menyangkali hal-hal yang supranatural dan mukjizat serta 
melihat kehendak manusia dan proses alam yang berproses sebagaimana mestinya sehingga Allah tidak dapat "memaksa" kehendak-Nya seperti yang sebutkan oleh Conn, bahwa menurut teologi proses, baik kebebasan manusia maupun proses alam yang biasa tidak ditakhlukkan kepada, atau diganggu oleh paksaan Ilahi. ${ }^{22}$

\section{e. Allah Tidak Ada}

Kemungkinan jawaban keempat adalah menyangkal keberadaan Tuhan. Dalam hal ini, penderitaan digunakan sebagai dasar untuk menolak keberadaanNya, atau menjadi dasar pembenaran pemahaman atheisme. Di mana definisi tradisional tentang theisme adalah pandangan akan keberadaan Allah, sebaliknya atheisme adalah tidak ada Allah. Atheisme bukan sesuatu yang baru muncul belakangan ini, melainkan merupakan satu kecenderungan yang dapat ditemukan di dunia kuno. Sedangkan di dunia Barat, atheisme berhubungan dengan penolakan iman Kristen, atau Allah dari Theis Yudaisme-Kristen, atau mungkin secara lebih luas lagi Allah Abraham. ${ }^{23}$ Seseorang yang berada dalam penderitaan sangat mungkin untuk sampai pada kesimpulan bahwa Allah tidak ada sekalipun dalam keadaannya yang "normal" mengakui keberadaan Allah. Jika Allah tidak ada, maka persoalannya adalah bahwa dapatkah ada moralitas yang baik tanpa Allah?

\section{f. Penderitaan sebagai Ujian dari Allah}

Salah satu kemungkinan jawaban yang muncul atas persoalan penderitaan orang saleh adalah bahwa penderitaan adalah sebagai ujian dari Allah dan ini adalah solusi yang paling umum diterima. Penderitaan sebagai ujian, juga menyajikan suatu proyek realisasi-keadilan pada masa yang akan datang. Dalam hal ini masa yang akan datang bukan waktu kehidupan setelah kematian, melainkan "suatu hari untuk menghukum" semua yang congkak dan angkuh serta menghukum semua yang meninggikan diri (Yes. 2:12), dan "hari-hari yang akan datang" untuk menerima ganjaran yang sempurna. Penafsiran terhadap teks Mazmur 11:5 menunjukkan bahwa penderitaan orang benar dapat dijelaskan sebagai ujian, saringan, dan akhirnya memperbaiki penderitaan. Sekalipun ada kemungkinan orang-orang percaya diizinkan oleh Tuhan untuk diuji kemurnian imannya namun tidak selalu demikian karena dengan demikian maka semua iman 
perlu diuji, dan sebaliknya bahwa mereka yang tanpa iman tidak perlu diuji. Fakta menunjukkan bahwa derita atau yang dalam bagian ini dilihat sebagai ujian dialami tidak hanya oleh orang percaya namun oleh semua manusia di dunia ini.

\section{SOLUSI TERHADAP PERSOALAN PENDERITAAN ORANG SALEH}

Penulis mencatat pemikiran yang berbeda tentang jawaban atas penderitaan manusia, khususnya penderitaan orang-orang saleh dengan mengacu kepada pemikiran Kreeft, yang menganalisa jalannya logika dengan mempertimbangkan syarat, tempat, proses argumentasi serta kesimpulan. Menurutnya, jika syarat tidak ambigu, jika tempat tidak palsu, dan jika proses argumentasi tidak logis atau keliru, maka kesimpulannya terbukti benar dan tidak ada alasan untuk menentangnya. ${ }^{24}$ Jalannya logika berdasarkan syarat tersebut ketika dihubungkan dengan penderitaan orang saleh maka menghasilkan beberapa kesimpulan yaitu: Pertama, premis iman bahwa Allah itu adil. Kedua premis rasio bahwa adil berarti memberikan imbalan kepada kebaikan dan menghukum kejahatan, ketiga premis akal sehat berarti bahwa imbalan membuat bahagia. Serta keempat, premis eksperimen yaitu bahwa penderita tidak bahagia. Dengan demikian kesimpulannya adalah bahwa penderita adalah orang jahat. Selanjutnya penulis akan melihat ambiguitas pengertian dalam masing-masing premis tersebut.

\section{a. Kebaikan Tuhan Berbeda dengan Kebaikan Manusia}

Premis pertama menyatakan bahwa Allah itu baik dan terpercaya. Pernyataan ini ambigu karena kebaikan Allah tidak berarti hal yang sama persis dengan kebaikan manusia karena Allah bukan manusia. Allah maha kasih namun Kasih-Nya tidaklah sama dengan kasih manusia. Kreeft menggunakan istilah "kebaikan proporsional" ketika ia menjelaskan bagian ini. Terlepas dari pembahasan tentang kebaikan Tuhan, dalam kebaikan yang ditunjukkan manusia tercermin bahwa kata baik dan kasih, bukan berarti memberikan segalanya, dan tidak mendisiplin. Hubungan orang tua dengan anak menunjukkan bahwa sejahat apapun seseorang, sebagai orang tua ia akan memberikan pemberian yang baik kepada anaknya (Mat 7:11). Tentu saja dengan pengecualian dalam kasus-kasus tertentu ada orang tua yang "merusak" anaknya. Pemberian yang baik bukan berdasarkan penilaian si anak namun berdasarkan penilaian orang tua. Demikian 
juga dengan menjalankan disiplin kepada anak bukan berarti merupakan suatu tindakan yang tidak baik, karena penggunaan "rotan" diperlukan dan bermanfaat bagi anak (Amsal 23:14).

Hal ini juga berlaku dalam hubungan antara umat dengan Allahnya yang dalam kekristenan Allah disapa dengan Bapa. Dengan demikian keadaan derita khususnya penderitaan orang-orang saleh tidak menunjukkan bahwa Allah tidak baik, sebaliknya menunjukkan bahwa Allah itu baik. Namun demikian, kebaikanNya jangan disamakan dengan kebaikan manusia sekalipun dalam proporsi tertentu ada dalam kebaikan manusia. Implikasinya jauh lebih luas tidak hanya dalam melihat kebaikan Tuhan ketika seseorang berada dalam penderitaan namun juga dapat diterapkan dalam hubungannya dengan sesama yaitu bahwa ketika, "derita" disebabkan oleh sesama tidak selalu itu adalah suatu kejahatan melainkan dapat dilihat sebagai kebaikan serta mendatangkan kebaikan.

\section{b. Keadilan Tuhan Berbeda dengan Keadilan Manusia}

Istilah ambigu dalam premis kedua adalah istilah "keadilan". Kata adil menurut kamus Bahasa Indonesia berarti; sama berat, tidak berat sebelah; tidak memihak, sepatutnya; tidak sewenang-wenang. ${ }^{25}$ Ketika pengertian harafiah seperti ini diterapkan pada keadilan Allah maka keadilan berarti kesetaraan atau setidaknya memiliki kesempatan yang sama, sesuatu yang menyerupai matematika, misalnya semua sama di depan hukum. Namun menurut Kreeft ini bukanlah arti terdalam dari keadilan.Ada keadilan dalam musik yaitu harmoni, proporsi dan keterkaitan yang membuatnya menjadi indah tetapi tidak setara dan ini adalah sesuatu yang jauh lebih misterius, lebih sarat dengan makna, dan lebih indah. ${ }^{26}$ Isu tentang keadilan dalam Alkitab dan literatur lainnya dapat dibagi menjadi dua kategori utama yaitu keadilan manusia dan keadilan Allah. Beberapa perselisihan yang terjadi atau konflik peperangan dan memerlukan keadilan biasanya berhubungan dengan kepemilikan, perilaku ataupun keyakinan. ${ }^{27}$ Dengan demikian, seseorang yang mengalami derita tidak dapat menggunakan deritanya sebagai dasar argumentasi bahwa Tuhan tidak adil, sebab keadilan Tuhan berbeda dengan keadilan manusia.

\section{c. Kebahagiaan Obyektif dan dari Sudut Waktu akan Datang}


Dalam premis ketiga, istilah "bahagia" juga berarti ambigu. Dalam hal ini kata "bahagia" menurut Kamus Bahasa Indonesia berarti, beruntung dan keadaan atau perasaan senang tenteram atau bebas dari segala yang menyusahkan. ${ }^{28}$ Keadaan bahagia ini cenderung diidentifikasi sebagai; pertama, sesuatu yang segera dan sekarang, bukan di masa depan, yang masih jauh atau kekal. Kedua, sebagai perasaan subyektif sadar akan kepuasan atas keinginan dan bukan pada fakta objektif. Dalam hal ini "kebahagian" pada umumnya lebih dipengaruhi oleh subyektifitas serta dari sudut waktu kekinian. Menurut penulis, lebih "adil" jika melihat istilah bahagia secara obyektif dan juga dari segi waktu yang akan datang. Dalam hal ini penderitaan saat ini dapat dilihat sebagai sesuatu yang mengerjakan kebahagiaan di masa mendatang atau juga derita dilihat sebagai kebahagiaan itu sendiri. Kreeft menjelaskan bagian ini dengan menggunakan istilah kesehatan bahwa "kita bisa sehat namun merasa tidak sehat, seperti ketika kita merasa sakit kepala tetapi tidak ada yang salah dengan kita." ${ }^{29}$

\section{d. Kebahagiaan dalam Penderitaan}

Akhirnya, premis keempat juga berisi istilah yang ambigu yaitu bahwa penderita "tidak bahagia". Sebagaimana perkataan Tuhan Yesus dalam khotbah di bukit bahwa "berbahagialah orang yang berdukacita...". Ambiguitas lain dari istilah senang juga berlaku untuk premis keempat ini yaitu penderita dalam jangka waktu sementara tidak bahagia, tetapi dalam jangka panjang ia bahagia, bahkan dalam arti kepuasan. Dengan demikian, dapat penulis simpulkan bahwa bahagia atau tidaknya seseorang tidak sepenuhnya ditentukan oleh keadaan derita ataupun berkat yang dialaminya.

\section{e. Kemahakuasaan Tuhan dalam Penderitaan}

Persoalan teologis antara eksistensi Allah di satu sisi dan eksistensi kejahatan di sisi lain mengakibatkan sifat Tuhan yang maha kuasa selalu dikontraskan dengan kekerasan dan penderitaan. Ketika mengontraskan sifat Tuhan segala maha dengan kekerasan dan penderitaan maka akan sampai pada kesimpulan bahwa seolah-olah Tuhan tidak berkuasa. Dalam bagian ini penulis hendak menekankan bahwa kemahakuasaan Tuhan, berarti Dia memiliki kuasa untuk menciptakan, memelihara atau menghancurkan apapun dan bahwa Dia tidak 
terbatas oleh hukum alam.Dengan demikian ketika seseorang berada dalam penderitaan, dan Tuhan tidak mencegah penderitaan itu bukan berarti Tuhan tidak berkuasa, sebaliknya bahwa kemahakuasaan-Nya ditunjukkan di dalam dan melalui derita orang-orang saleh.

\section{AKIBAT DERITA}

Penderitaan manusia dan penyebabnya sangat kompleks. Itulah sebabnya tidak ada satu penjelasan yang lengkap dan memadai tentang tema penderitaan ini. Namun demikian, penulis melihat dampak penderitaan secara umum dalam kehidupan manusia, bahwa penderitaan dapat berdampak secara negatif maupun positif terhadap penderita yang dalam hal ini penulis mengacu kepada istilah yang digunakan oleh Croy yaitu; Penderitaan destruktif dan Penderitaan transformatif.

\section{a. Penderitaan Destruktif}

Sekalipun penderitaan dapat bermakna positif bagi penderita atau yang dalam pembahasan selanjutnya disebut dengan penderitaan transformatif, namun tidak semua penderitaan adalah transformatif. Beberapa orang sederhana diliputi oleh penderitaan destruktif yang dapat dilihat dalam kehidupan sehari-hari. Dalam konteks ini, penderitaan dapat "merusak" seseorang di berbagai bidang kehidupan, apakah itu pekerjaan, keluarga, pelayanan, dalam hubungan sosial dengan sesama, maupun kehidupan rohani. Misalnya, penderitaan secara ekonomi seperti kemiskinan dapat mendesak seseorang untuk melakukan pencurian, penipuan perampokan, pelacuran dan sebagainya. Atau ketika seseorang berada dalam penderitaan maka pelariannya adalah dengan mengonsumsi zat-zat adiktif seperti narkoba dan minuman keras dengan alasan bahwa dengan mabuk sejenak dapat melupakan penderitaannya. Mungkin untuk sementara penderitaannya dapat dilupakan, namun persoalannya adalah apakah hal itu berarti persoalan deritanya terselesaikan? ataukah sebaliknya menjadi semakin parah dan menimbulkan persoalan derita yang baru?

Masalah penderitaan dalam konteks relasi sosial seperti karena derita kehilangan orang-orang terkasih dan menjadi bahan gosip tetangga. Beberapa orang akan memilih untuk berpindah tempat tinggal, berganti pekerjaan, berpindah gereja, dan seterusnya dengan harapan dapat menyelesaikan persoalan 
"deritanya". Dalam hal ini, penting untuk direnungkan bahwa apakah dengan melakukan hal tersebut dapat mengatasi penderitaannya? dan kemudian apakah dapat dijamin bahwa tidak akan ada persoalan di tempat yang baru dengan relasi yang baru? Menurut penulis, keputusan semacam ini adalah usaha untuk melarikan diri dari persoalan yang pada akhirnya tidak menyelesaikan masalah deritanya sebaliknya akan menciptakan "derita" yang baru.

Dari segi kehidupan rohani, dalam pelayanan penulis menyaksikan umat Tuhan yang karena deritanya mengakibatkan hubungannya dengan Tuhan terganggu sehingga praktisnya ia tidak lagi berdoa ataupun beribadah di gereja. Demikian juga dengan para pelayan Tuhan yang akhirnya meninggalkan pelayanannya karena tidak kuat menghadapi penderitaannya.Fenomena ini dapat dilihat pada orang-orang yang dahulunya begitu dekat dengan Tuhan namun sekarang begitu jauh. Orang-orang yang dahulunya begitu setia dalam pelayanan namun sekarang begitu antusiasnya untuk menghalangi pelayanan.

Berhubungan dengan tema penderitaan destruktif ini menurut Stoeber, banyak di antara mereka khususnya anak-anak, tidak mampu untuk bertumbuh ketika mereka berada dalam penderitaan. ${ }^{30}$ Artinya bahwa anak-anak akan mampu menyelesaikan masalah penderitaannya menurut tingkatan usia dan kematangannya masing-masing. Dapat penulis simpulkan bahwa ketidakdewasaan menjadi dasar kenapa penderitaan merusak kehidupan seseorang, sebaliknya kedewasaan akan memampukan seseorang untuk menyelesaikan persoalan deritanya sendiri.

Dalam bagian ini penulis menggunakan istilah "masalah" secara bersamaan maupun bergantian dengan istilah "penderitaan" untuk menggambarkan penderitaan itu sendiri. Di mana ukuran besar kecilnya masalah derita seseorang tidak ditentukan oleh penderitaan itu sendiri melainkan oleh kemampuan orang tersebut untuk menyelesaikannya. Artinya bahwa terhadap masalah yang sama, ketika diperhadapkan pada dua orang yang berbeda dengan tingkat kedewasaan yang berbeda maka akan dilihatnya juga secara berbeda. Penderitaan yang sama akan menjadi masalah besar bagi orang dengan tingkat kedewasaan yang rendah sebaliknya akan menjadi masalah kecil bagi orang dengan tingkat kedewasaan yang lebih tinggi. Dalam hal ini kedewasaan menjadi penting dalam menghadapi berbagai persoalan penderitaan orang saleh. 


\section{b. Penderitaan Transformatif}

Penulis meyakini bahwa semua orang normalnya tidak menghendaki adanya penderitaan. Namun penderitaan itu tidak dapat dielakkan oleh setiap orang karena pada dasarnya penderitaan adalah bagian dari panggilan Allah bagi Gereja. Penderitaan itu juga tidak dapat ditaklukkan oleh setiap orang, karena persoalan penderitaan dapat ditaklukan secara sempurna nanti pada masa eskatologi. ${ }^{31}$ Itulah sebabnya mereka yang menganggap bahwa penderitaan tidak dikehendaki oleh Allah pada dasarnya menyangkali akan panggilan Allah. Menurut Stoeber, manusia belajar melalui penderitaan, mengubah pengalaman yang mengarahkan kepada hikmat. ${ }^{32}$ Dalam pandangan ini, penderitaan dipahami sebagai sesuatu yang memainkan peran positif dengan sangat kuat dalam kehidupan. Dapat dikatakan bahwa penderitaan memberikan manfaat, tujuan, dan dipahami sebagai memberikan kontribusi yang positif pada akhirnya. Hal ini adalah respons agama terhadap masalah penderitaan yang sangat tua dan tradisional. Memaknai penderitaan secara positif seperti ini dimungkinkan ketika seseorang dapat melihat masalah penderitaan sebagai ujian dan bukan sebagai hukuman. Dan dengan demikian masalah penderitaan menjadi batu loncatan untuk meraih hal-hal yang lebih besar, atau juga sebagai indikator kenaikan tingkat kedewasaan, dan bukan sebagai batu sandungan yang menyebabkan seseorang terjatuh bahkan sampai tergeletak.

Wright, menekankan pada perspektif teologi yang memberi kesan bahwa penderitaan merupakan bagian dari penebusan dan kualitas transformatif. ${ }^{33}$ Argumentasi Wright tersebut didasarkan pada karya penebusan Kristus yang mentransformasikan kehidupan manusia. Selain itu dalam penyelidikannya, menemukan bahwa hubungan penderitaan dan sukacita tidak mungkin dipisahkan, keduanya merupakan satu sisi koin yang sama. Dengan demikian dalam setiap penderitaan ada sukacita atau dengan kata lain penderitaan mendatangkan sukacita. Oleh sebab itu, bersukacitalah dalam menghadapi penderitaan seperti yang dituliskan oleh Yakobus bahwa, anggaplah sebagai suatu kebahagiaan, apabila kamu jatuh ke dalam berbagai-bagai pencobaan (Yak. 1:2). Namun hal ini bukan berarti bahwa seseorang harus menghendaki atau mencari masalah 
penderitaan. Dalam konteks ini penderitaan sebagai cobaan yang terjadi atas izin Allah dan bukan karena penderitaan yang disebabkan oleh kesalahan diri sendiri.

Croy mendemonstrasikan gambaran latihan fisik dalam atletik dan mengombinasikannya dengan disiplin moral. Penafsirannya terhadap penderitaan adalah saling memperkuat khususnya ketika istilah paidea (disiplin) dipahami sebagai arti non-hukuman. Menurutnya kitab Ibrani 12:1-13 tidak mendukung pandangan penderitaan sebagai hukuman. Namun tidak dapat dikatakan bahwa semua penderitaan adalah non-hukuman dan mendidik. Interpretasi yang melihat penderitaan manusia sebagai non-hukuman adalah yang paling sedikit namun terdapat beberapa contoh penderitaan yang didukung oleh kitab suci Yahudi dan Kristen. ${ }^{34}$ Kadang beberapa kebaikan besar dapat tercapai hanya dengan jalan terlibat dalam penderitaan dan benar bahwa usaha dapat dilakukan untuk mencapainya walaupun menderita. Mengutip pernyataan Swinburne bahwa, orang tua seharusnya mengizinkan anak-anak untuk menderita kesakitan gigi susu, demi kepentingan menghasilkan gigi yang sehat. Tetapi Allah tidak seperti orang tua manusia, ia dapat menghasilkan gigi yang sehat tanpa perlu sakit karena operasi gigi. ${ }^{35}$ Dalam hal ini penulis ingin menekankan bahwa penderitaan dapat menjadi penderitaan transformatif namun tidak selamanya transformasi harus melewati jalan penderitaan.

Selain itu, respons manusia terhadap adanya bahaya dan kesakitan memberikan kekuatan dalam usaha untuk melihat sumber penderitaan dan untuk menemukan jalan keluar serta untuk membentuk atau mengenali solidaritas komunitas-dengan kelompok lainnya dan makhluk lainnya. ${ }^{36}$ Dalam hal ini manusia merespons secara positif terhadap penderitaan dan ini menjadi kekuatan yang dapat mentransformasikan. Akhirnya masalah penderitaan dalam bentuk apapun yang terjadi atas umat Allah, Allah tetap menyertai mereka. Umat Allah mengetahui bahwa Roh Allah berdiam dalam diri mereka sendiri dan dalam persekutuan mereka dengan penderitaan melalui persekutuan dalam penderitaan Kristus. ${ }^{37}$ Penyertaan Tuhan, memampukan setiap umat Tuhan untuk menghadapi dan mengatasi masalah penderitaan dan bukan meniadakannya. Dan sering kali ada doa yang dipanjatkan kepada Tuhan supaya masalah penderitaan diangkat. Dalam hal ini penulis menyarankan untuk menggantikan doa yang demikian dengan doa supaya diberikan kekuatan dalam menghadapi persoalan penderitaan. 


\section{KESIMPULAN}

Pada hakikatnya penderitaan dialami oleh semua orang di mana saja. Penderitaan baik secara fisik, psikis maupun rohani. Penderitaan itu sendiri disebabkan oleh banyak faktor namun dalam hal ini penulis mengklasifikannya sebagai penderitaan yang secara suka rela diambil oleh penderita dan penderitaan yang ditimpakan kepada penderita. Secara khusus penderiaan orang saleh dan sifat Allah menjadi persoalan teologis yang tidak terselesaikan namun dalam bagian ini terletak rahasia Allah itulah sebabnya dapat penulis sebutkan bahwa penderitaan meliputi penderitaan yang dapat dimengerti oleh manusia dan penderitaan yang hanya dapat dimengerti oleh Allah. Berbagai kemungkinan jawaban atas penderitaan orang benar, memiliki alasannya masing-masing dan beberapa di antaranya dikuatkan oleh kesaksian Alkitab namun penekanan penulis bahwa, satu kemungkinan jawaban tidak dapat digeneralisir untuk semua kasus penderita. Penulis mencatat solusi terhadap persoalan penderitaan orang saleh dengan penekanan pada sifat Allah yang: mengasihi, adil, maha kuasa. Di mana kasih, keadilan, dan kuasa Allah tidak sama dengan pengertian kasih, keadilan dan kuasa manusia. Dari segi manusia, kebahagiaan dapat terjadi karena penilaian subjektif dan hanya dari segi waktu kekinian. Itulah sebabnya perlu juga untuk melihat secara objektif dan dari segi waktu yang akan datang bahwa tidak untuk selamanya seseorang menderita. Penderitaan dapat berdampak positif (transformatif) tetapi juga negatif (destruktif) bagi penderita. Besar kecilnya masalah derita tidak ditentukan oleh penderitaan itu sendiri melainkan oleh tingkat kedewasaan seseorang.Itulah sebabnya kedewasaan dipelukan dalam menghadapi berbagai penderitaan.

\section{Endnotes:}

\footnotetext{
${ }^{1}$ Peter Kreeft. Three Philosophies of Life. Ecclesiastes: Life as Vanity, Job: Life as suffering, Song of Song: life as love. (San Francisco: Ignatius Press,1989), hlm.68

${ }^{2}$ R. Laird, Harris (khamas) dalam R. Laird Harris (ed), Theological Wordbook of The Old Testamen (TWOT), Volume 1, (Chicago: Moody Press, 1980), hlm. 297 hlm. 144

${ }^{4}$ John N. Oswalt, כּ (kāa'ab) dalam R. Laird Harris (Editor). Theological Wordbook of The Old Testamen, Volume 1.(Chicago: Moody Press, 1991), hlm. 425
} 
5 John E. Hartley. צעק (tsā'aq) "dalam” R. Laird Harris. (Ed). Theological Wordbook of The Old Testamen, Volume 2.(Chicago: Moody Press, 1991), hlm. 772

${ }^{6}$ Gerda de Villiers. Sin, Suffering, Sagacity: Genesis 2-3. "dalam" Bob Becking and Dirk Human (Edited). Exile and Suffering A Selection of Papers Read at the 50th Anniversary Meeting of the Old Testament Society of South Africa OTWSA/OTSSA Pretoria August 2007. (Leiden, Boston: Koninklijke Brill NV, 2009), hlm. 16

${ }^{7}$ Bob Becking. Does Exile Equal Suffering?A Fresh Look at Psalm 137. "dalam” Bob Becking and Human. Exile and Suffering. Ibid, hlm.201

${ }^{8}$ W. R. F. Browning. Kamus Alkitab. A Dictionary of the Bible.(Jakarta: PT. BPK Gunung Mulia, 2007), hlm. 80

9James H. Cone. From Black Theology and Black Power."dalam" Liberating Faith. Religious Voices for Justice, Peace, and Ecological Wisdom (Edited by Roger S. Gottlieb).Lanham, Boulder, New York, Toronto, oxford: Rowman \& Littlefield Publihers, Inc. 2003), hlm.189

${ }^{10}$ Cone.From Black Theology, hlm.190

${ }^{11}$ Wayne Morris. Theology without Words.Theology in the Deaf Community.(Burlington: Ashgate Publishing Company, 2008), hlm.155

${ }^{12}$ Venerable Yifa.The Tender Heart.A Buddhist Response to Suffering.(New York: Lantern Books, 2007), hlm. 9

${ }^{13}$ Steven Kepnes.Rereading Job as textual theodicy "dalam" Robert Gibbs and Elliot R. Wolfson (Edited) Suffering Religion.(London and New York: Routledge, Taylor \& Francis Group, 2002), hlm. 36

${ }^{14}$ Victoria La'Prote. An Introduction to Theology.(Edinburgh : Edinburgh University Press, 2001), hlm. 63

${ }^{15}$ K. J. Illman. Theodicy in Job "dalam" Antti Laato., Johanes C. de Moor (Editors).Theodicy in the World of the Bible. (Leiden, Boston :Koninklijke Brill NV, 2003), hlm. 304

${ }^{16}$ Michael Lerner. The Struggle between Two Voices of God in Torah "dalam" Liberating Faith.Religious Voices for Justice, Peace, and Ecological Wisdom (Edited by Roger S. Gottlieb).Lanham, Boulder, New York, Toronto, oxford: Rowman \& Littlefield Publihers, Inc. 2003), hlm.105

${ }^{17}$ N. Clayton Croy. Endurance in Suffering. Hebrew 12:1-3 in its Rethorical, Religious, and Philosophical Context.(Cambridge: Cambridge University Press. 1998), hlm. 222

${ }^{18}$ Wright.God I Don't Understand, hlm. 217

${ }^{19}$ Kreeft.Three Philosophies of Life, hlm. 6

${ }^{20}$ David Kraemer. Responses to Suffering in Classical Rabbinic Literature. (New York, Oxford: Oxford University Press, 1995), hlm. 34.

${ }^{21}$ Illman.Theodicy in Job, hlm. 318

${ }^{22}$ Harvie M. Conn. Teologi Kontemporer.(Malang: Seminari Alkitab Asia Tenggara, 1991). 104

${ }^{23}$ David Ferguson.Faith and its Critics.A Conversation.(Oxford: Oxford University Press, 2009), hlm. 16

${ }^{24}$ Kreeft.Three Philosophies of Life, hlm.68

25 Kamus Bahasa Indonesia, hlm.12

${ }^{26}$ Kreeft.Three Philosophies of Life, hlm. 73

${ }^{27}$ Nancy M. Tischler. Thematic Guide to Biblical Literature.(London: Greenwood Press, 2007), hlm. 177

$28 \quad$ Kamus Bahasa Indonesia, hlm.115

${ }^{29}$ Kreeft.Three Philosophies of Life, hlm.74

${ }^{30}$ Stoeber.Reclaiming Theodicy, hlm. 60

${ }^{31}$ Croy.Endurance in Suffering, hlm. 224

${ }^{32}$ Stoeber, Reclaiming Theodicy, hlm. 18

${ }^{33}$ Wright.God I Don't Understand, hlm. 46

${ }^{34}$ Croy.Endurance in Suffering, hlm. 219

${ }^{35}$ Swinburne. The Existence of God, hlm. 237

${ }^{36}$ Roger S. Gottlieb.The Justice of Transcendence and the Transcendence of Justice" "dalam" Liberating Faith.Religious Voices for Justice, Peace, and Ecological Wisdom (Edited by Roger S. Gottlieb).Lanham, Boulder, New York, Toronto, oxford: Rowman \& Littlefield Publihers, Inc. 2003), hlm. 117

${ }^{37}$ Stoeber.Reclaiming Theodicy, hlm.47 


\section{DAFTAR PUSTAKA}

Becking Bob, 2009. Does Exile Equal Suffering?A Fresh Look at Psalm 137. "dalam" Bob Becking and Dirk Human $(E d)$. Exile and Suffering A Selection of Papers Read at the 50th Anniversary Meeting of the Old Testament Society of South Africa OTWSA/OTSSA Pretoria August 2007. Leiden, Boston: Koninklijke Brill NV

Browning W. R. F, 2007. Kamus Alkitab. A Dictionary of the Bible. Jakarta: BPK Gunung Mulia.

Cone James H, 2003. From Black Theology and Black Power."dalam" Liberating Faith. Religious Voices for Justice, Peace, and Ecological Wisdom Edited by Roger S. Gottlieb.Lanham, Boulder, New York, Toronto, oxford: Rowman \& Littlefield Publihers, Inc.

Conn, Harvie M. 1991. Teologi Kontemporer. Malang: Seminari Alkitab Asia Tenggara.

de Villiers Gerda, 2009. Sin, Suffering, Sagacity: Genesis 2-3. dalam Bob Becking and Dirk Human (Ed). Exile and Suffering A Selection of Papers Read at the 50th Anniversary Meeting of the Old Testament Society of South Africa OTWSA/OTSSA Pretoria August 2007. Leiden, Boston: Koninklijke Brill NV.

Ferguson David, 2009. Faith and its Critics.A Conversation. Oxford: Oxford University Press.

Gottlieb Roger S, 2003. The Justice of Transcendence and the Transcendence of Justice" dalam Liberating Faith.Religious Voices for Justice, Peace, and Ecological Wisdom Edited by Roger S. Gottlieb.Lanham, Boulder, New York, Toronto, oxford: Rowman \& Littlefield Publihers, Inc.

Illman K. J, 2003. Theodicy in Job "dalam" Antti Laato., Johanes C. de Moor $(E d) . T h e o d i c y$ in the World of the Bible. Leiden, Boston : Koninklijke Brill NV. 2008.Kamus Bahasa Indonesia.Jakarta: Pusat Bahasa

Departemen Pendidikan Nasional. 
Kepnes Steven, 2002. Rereading Job as textual theodicy "dalam” Robert Gibbs and Elliot R. Wolfson (Ed) Suffering Religion. London and New York: Routledge, Taylor \& Francis Group.

Kraemer David, 1995. Responses to Suffering in Classical Rabbinic Literature. New York, Oxford: Oxford University Press, 1995

Kreeft, Peter, 1989. Three Philosophies of Life. Ecclesiastes: Life as Vanity, Job: Life as suffering, Song of Song: life as love.San Francisco: Ignatius Press.

La'Prote Victoria, 2001.An Introduction to Theology.Edinburgh : Edinburgh University Press

Lerner Michael, 2003. The Struggle between Two Voices of God in Torah "dalam" Liberating Faith.Religious Voices for Justice, Peace, and Ecological Wisdom Edited by Roger S. Gottlieb.Lanham, Boulder, New York, Toronto, oxford: Rowman \& Littlefield Publihers, Inc.

Michael Stoeber, 2005.Reclaiming Theodicy Reflections on Suffering, Compassion and Spiritual Transformation. New York: Palgrave Macmillan.

Morris, Wayne, 2008. Theology without Words.Theology in the Deaf Community.Burlington: Ashgate Publishing Company.

N. Clayton Croy, 1998. Endurance in Suffering. Hebrew 12:1-3 in its Rethorical, Religious, and Philosophical Context.Cambridge: Cambridge University Press.

Nancy M. Tischler, 2007. Thematic Guide to Biblical Literature.London: Greenwood Press.

R. Laird Harris. (Ed). 1991. Theological Wordbook of The Old Testament, Volume 1, 2. Chicago: Moody Press.

Swinburne Richard, 2004. The Existence of God.Second Edition. Oxford: Clarendon Press

Wright Christopher J. H, 2009. God I Don't Understand. Reflections on Tough Questions of Faith. Michigan: Zondervan

Yifa, Venerable, 2007.The Tender Heart.A Buddhist Response to Suffering. New York: Lantern Books. 